\title{
SOME MACROECONOMIC CONSEQUENCES OF BASIC INCOME AND EMPLOYMENT SUBSIDIES
}

\author{
THOMAS MOUTOS \\ WILLIAM SCARTH
}

CESIFO WORKING PAPER No. 916

CATEGORY 3: SOCIAL PROTECTION

APRIL 2003

Presented at CESifo Conference on Labour Market Institutions and Public Regulation, June 2002

\footnotetext{
An electronic version of the paper may be downloaded

- from the SSRN website: Www.SSRN.com

- from the CESifo website: www.CESifo.de
} 


\title{
SOME MACROECONOMIC CONSEQUENCES OF BASIC INCOME AND EMPLOYMENT SUBSIDIES
}

\begin{abstract}
Two macro models - one for a closed economy and the other for a small open economy - are used to examine the scope for income redistribution and employment creation. In particular, the introduction of both a guaranteed annual income (basic income) and an employment subsidy are examined, and these policies are compared to a straightforward tax cut for (unskilled) labour. All initiatives are financed by a tax on capital. In the open-economy setting, capital is perfectly mobile, so there is a trade-off between the direct benefits of each policy, and the costs that follow from the out-migration of capital. The model is used to assess the relative importance of these competing effects.
\end{abstract}

JEL Code: E24, E62, H23.

Keywords: guaranteed annual income, subsidies, capital taxes, redistribution.

Thomas Moutos

DIEES

Athens University of Economics and Business

Patission 76

Athens 10434

Greece

tmoutos@aueb.gr
William Scarth

Department of Economics

McMaster University

Hamilton, Ontario L8S 4M4

Canada

scarth@mcmaster.ca

Paper presented at the CESifo-ISPE conferences on "Labour Market Institutions and Public Regulation," at Munich, October 26-27, 2001 and Cadenabbia, June 2-4, 2002. We wish to thank our discussants, Martin Werding and Marcel Thum, the organizers (Jonas Agell, Michael Keen and Alfons Weichenrieder), two anonymous referees and the conference participants for many helpful comments and suggestions. Finally, we are grateful to Manos Matsaganis, Apostolis Philippopoulos, Krishna SenGupta and those attending the seminar at the University of Canterbury (July 19, 2002) for very helpful input. 


\section{Introduction}

Recent years have witnessed both growing income inequality and persistently high unemployment. In the United States and in the United Kingdom, the worsening prospects have taken the form of decreases in the real earnings of lower-skilled workers - the real hourly wages of young males with 12 or fewer years of schooling has dropped by more than 20 percent in the last two decades. In continental Europe, real wages at the bottom of the skill distribution have risen, but at the cost of significant increases in unemployment especially for this group (Freeman (1995), Machin and Van Reenen (1998)). Although there have been competing explanations concerning the primary reasons behind these phenomena, for some authors the increased pace of global economic integration (popularly referred to as globalization) has had a major role to play (see, for example, Wood (1995) and Rodrik (1997)). ${ }^{1}$ Moreover, in conjunction with the need for more social insurance programs - which the increased exposure to globalization generates many authors fear that globalization (of capital markets in particular) erodes the ability of the nation state to satisfy these needs. According to this view, governments will find it increasingly difficult to raise revenue from the taxation of mobile factors of production. As a result, redistribution and employment creation are viewed as initiatives that may be increasingly difficult to pursue.

These developments have stimulated renewed interest in policies that may redistribute income in ways that minimize undesirable indirect effects. This is particularly so since one of the usual charges made against the social welfare system is that in many countries it nourishes a collectively sub-optimal incentive structure, ranging from excessive early retirement to "poverty traps" for unemployed workers (especially single mothers) who 
return to low-wage employment. In many countries, the implicit tax rate at the low end of the earnings distribution is often very large because of the phasing out of transfer programs as income rises. For example, Atkinson and Sutherland (1990) report that in Britain in 1989 almost half a million families faced marginal tax rates of 70 per cent or higher, as a result of means-tested social assistance benefits. Blundell and MaCurdy (1999) also provide an extensive analysis of marginal tax rates faced by low-income households in the US and in the UK, and show that the implicit tax rate may sometimes exceed $100 \%$ when two or more transfer programs are phased-out simultaneously. Despite these costs, the welfare state can still have a net positive (efficiency enlarging) effect in modern industrialized economies. Indeed, as Sinn (1995) and Atkinson (1999) have persuasively argued, the welfare state should not be viewed as something that only disturbs the market process. Especially in a second-best setting, it is something that can encourage risk-taking, foster efficiency and facilitate the growth process.

In this paper, we argue that the fears regarding globalization may be exaggerated. We show that, in a second-best setting, even when taxing perfectly mobile factors, governments can acquire the necessary revenue to facilitate policies that can both reduce unemployment and increase the incomes of those already working. As a base for comparison, we first examine a closed economy in which the source of the second best lies in the labour market. The payment of efficiency wages by firms intent on maximizing profits results in involuntary unemployment. Then, we focus our attention on small openeconomy framework.

Three policies are considered. The first involves the unconditional payment of a guaranteed income to all citizens. The features that distinguish the Basic Income (BI) 
proposal - variously called "guaranteed annual income", "universal basic income", or “demogrant" (see, Meade (1948, 1972), Tobin et al. (1967), Atkinson (1995), Van Parijs $(1995,2000))$ - from other social security proposals, are that it is paid irrespective of any other income, it does not require any present or past work performance, it is not conditional on the willingness to accept a job, and it is paid to individuals rather than households (Van Parijs, 1992). Some proponents argue that a BI system should be accompanied by widespread social security reform, including deregulation of the labour market. For Atkinson (1995), the BI proposal, in its pure form, would replace all social security benefits and it would be accompanied by a flat comprehensive income tax rate that would replace the existing income taxes and social security contributions. ${ }^{2}$ In this way, proponents of BI hope to provide a solution to the "impossible trinity" of welfare reform objectives: to raise the living standards of low-income families, to encourage employment, and to keep budget costs low.

The second policy proposal involves the government paying employment subsidies to firms (as advocated by Phelps (1997) and Solow (1998)). The direct aim of this policy is not so much to increase worker's income but to reduce the unemployment rate. It could, nevertheless, indirectly help those remaining unemployed after the enactment of the policy if it results in higher wage rates and unemployment benefits (if the replacement ratio stays constant).

The third policy we examine is more straightforward, in the sense that it does not involve the government setting up an entirely new program. Instead, it involves simply the lowering of the tax rate applied to labour income. 
Throughout our analysis, we assume that all initiatives - basic income, employment subsidies and household wage-income tax cuts - are financed by raising the tax on capital - which is a perfectly mobile factor in the open-economy case. We make this financing assumption, despite the fact that some proponents of BI expect this initiative to be financed by cuts in existing social programs. We do so for two reasons. First, we want to examine the possibility of redistribution - especially in an open economy setting. All previous analyses of the effects of introducing BI have assumed that it will be "financed" by cutting down on existing social security programs in a closed economy setting (see, Bowles (1992), Atkinson (1995), Groot and Peters (1997), Van der Linden (1999, 2000)).

Second, we are concerned about political feasibility. In this respect we note that even within the European Union, there are significant differences across countries in the relative importance attached to redistributive social policy goals, in the instruments used, and in the extent to which social policy achieves its intended effects. ${ }^{3}$ The evolution of the social welfare system in each country has created constituencies that strongly resist any reductions in the benefits to which they have become "entitled." Even more importantly, for many supporters of advanced European welfare states, the fully developed welfare state deserves priority over BI because it is considered to accomplish what BI can not: it guarantees that certain specific human needs will be met. It is argued that although both the current advanced welfare states and BI can reduce inequality of "condition," the welfare state does so with greater efficiency because it takes better account of inequalities due to differences in needs. For example, if person A needs expensive medical treatment and person B does not, giving both of them a BI grant will not go far to make their situations more equal; only the public provision of health 
services has the chance of accomplishing that (see, Bergmann (2001)). Thus, both to respect this political feasibility constraint, and to address some of the concerns raised about globalization, we consider financing all initiatives by taxing the "rich."

The remainder of the paper is organized as follows. In section 2, we introduce the macro model that underlies the paper's conclusions. It is quite standard and highly simplified. There are two factors of production: labour (which we think of as unskilled, since the government wishes to raise workers' incomes), and "capital" (which we think of as standing for both physical capital and skilled labour - the source of the human capital that is also to be taxed). It is assumed that the owners of capital are the "rich". To the extent that "capital" involves skilled workers, we make the assumption that these individuals find their employment so rewarding that the possibility of reduced efficiency and effort on the job does not arise. But with the less skilled who do not have "good" jobs, it is assumed that these individuals are dissatisfied with their work. It is, therefore, in firms' interest to pay efficiency wages to generate the profit-maximizing level of labour productivity. We use Summers' (1988) compact exposition of efficiency wages to specify this set up for the "labour" input in our model. All initiatives that are designed to help labour are financed by taxing the owners of capital. In the closed-economy setting, these "rich" individuals cannot migrate to escape this taxation; in the small openeconomy setting they can.

In sections 3 and 4 , the results for the closed-economy and small open-economy versions of the model are explained. In sections 5 and 6 , we consider a sensitivity test (allowing unemployment to follow from unions instead of efficiency wages), we discuss several possible extensions of the analysis, and we offer concluding remarks. 


\section{The Model}

There are two factors of production: labour $(L)$ and capital $(K)$. Since we think of "labour" as unskilled and deserving of some government attention, and since it is more difficult for such individuals to move great distances, we assume that labour is immobile internationally. (We set $L=1$.) In contrast, in the open-economy setting, we assume that capital can move in and out of the country without cost.

Firms (correctly) believe that wages exert an influence on the productivity (effort) of their workforce. Firms have an incentive to manipulate the wage offered to the unskilled so that costs per efficiency unit of unskilled labour are minimized. As a result, the wage rate exceeds the level that would clear the market, and this determines the equilibrium unemployment rate for labour. Firms have no incentive to pay a similar premium for capital. Thus, capital is paid its marginal product, and in the open-economy case, capital mobility insures that the after-tax return is determined exogenously in the rest of the world.

We view the unemployment that emerges in an efficiency-wage setting as "involuntary". This is why it is appropriate for the government to consider intervening with a policy initiative. Efficiency wage theories are based on market failure - the premise that employers cannot acquire full information about the productivity of their workers (see, for example, Akerlof and Yellen (1986)). This proposition is reflected in most employment contracts, since they do not involve precise specifications of productivity. A higher wage offer by the firm may increase the average productivity of its workforce for several reasons. First, a high-wage firm may (on average) attract workers of higher quality. Second, a higher wage increases the magnitude of punishment incurred 
by a worker who is fired after being found offering a sub-standard amount of effort. Third, high wages may lead workers to believe that they are treated "fairly", and they may reciprocate to this "gift" by offering higher effort. The implication of this dependence of worker productivity on wages is that the firm will want to choose a wage rate such that the marginal benefit from a wage increase is equated with the associated increase in costs. Thus, the profit-maximizing wage rate chosen by firms is compatible with involuntary unemployment. The unemployed may be willing to work at lower wages, yet if firms employ them, marginal revenue would decline more than marginal cost.

The firms' production function is:

$$
Y=K^{1-\gamma}(b L)^{\gamma} .
$$

$\gamma$ is a positive fractions, and $b$ is the index of work effort. We rely on a particularly compact version of efficiency wages (due to Summers (1988) and highlighted by Romer (2001)), which is compatible with any of the motivations mentioned above (and which is more readily calibrated than the Shapiro and Stiglitz (1984) specification - see Pissarides (1998)). Following Summers, we specify $b$ as:

$$
b=[(w(1-t)+p w)-x]^{\alpha} .
$$

The term in round brackets defines what individuals receive if they are working; $x$ denotes their alternative option that is available should they leave their current job. $t$ is the income tax rate applied to labour earnings, and $p$ is a parameter that defines BI. This parameter measures the generosity of an unconditional (and tax-free) transfer of income from the government to all (unskilled) individuals - independent of employment status. We assume that this BI (which is the same for all individuals) is proportional to the wage 
rate. $\alpha$ is a positive fraction; as a result, a higher wage in the current job raises each worker's return relative to her alternative, and thereby induces higher productivity. The worker's alternative option is defined as

$$
x=(1-u)(1-t) w+u f w+p w
$$

where $f$ is a parameter measuring the generosity of the unemployment-insurance system. That is, benefits paid to the unemployed are a proportion $(f)$ of the wage, and these benefits are untaxed. The worker's alternative option is a weighted average of the wage offered at other firms (which equals $w$ in full equilibrium) and what is received if the individual cannot find work. The weights are the employment rate, $(1-u)$, and the unemployment rate, $u$, respectively. When firms optimize, they regard $x$ as independent of their individual wage and employment decisions.

Each firm's profit function is:

$$
\pi=Y-(w-Q) L-r K
$$

$r$ is the interest rate (the wage or rent paid to each unit of capital); as above, $w$ is the wage rate; and $Q$ is a per-employee subsidy paid to the firm. We assume that $Q$ is proportional to the economy-wide wage rate, that is: $Q=q w$. Nevertheless, when individual firms optimize, they do not think of this equation holding at the individual level. That is, when choosing $w$, firms do not think that the subsidy rate that they will receive depends on their individual wage policy.

Setting the derivatives of the profit function with respect to $w, L$ and $K$ equal to zero, manipulating the first-order conditions, and using the definition of $x$, we derive the following relationships:

$$
u=\alpha(1-q)(1-t) /(1-t-f)
$$




$$
\begin{aligned}
& (1-\gamma) Y / K=r \\
& \gamma Y / L=(1-q) w .
\end{aligned}
$$

Equation (4) states that the unemployment rate depends positively on the generosity of unemployment insurance and the wage-income tax rate paid by workers, and negatively on the subsidy rate paid to firms for employing individuals. Equation (5) states that the marginal product of capital should be set equal to the rental cost of capital. In similar fashion, equation (6) states that the marginal product of labour should be equal to its (net of subsidy) rental rate (the pre-tax wage).

In the open-economy setting, the assumption that capital is perfectly mobile internationally implies that its after-tax reward is equal to what prevails in the rest of the world. This implies that

$$
r(1-\tau)=\bar{r}
$$

where $\tau$ and $\bar{r}$ are the tax rate applied to capital rents, and the after-tax reward that can be had by the owners of capital in the rest of the world. Equation (7) constrains the government's ability to redistribute income, since it implies that the "rich" stand ready to withdraw their services to whichever degree is required to insulate their net returns from any taxes imposed.

There is one additional limitation on the government's use of fiscal incentives and transfers - the fact that it must respect its budget constraint. A balanced budget is stipulated in equation (8):

$$
G+f w u+p w+q w(1-u)=t w(1-u)+\tau r K
$$

It states that spending on goods $(G)$, unemployment insurance, unconditional income transfers (the BI), and employment subsidies must equal the sum of the two forms of 
income tax revenue. Equation (8) involves the definition that individuals must be either employed or unemployed:

$$
L=1-u .
$$

The open-economy version of the model involves equations (1) through (9) solving for $Y, L, K, u, w, r, b, x$ and one government policy variable (which is $p$ in the case of BI, $q$ in the case of employment subsidies, and $t$ with the wage-income tax cut). In each case, we impose an increase in the tax rate on capital, $\tau$. In the closed-economy case, equation (7) is dropped, and $K$ becomes an exogenous variable. Proceeding with the solution of the model, we first divide both sides of equation (8) by $Y$, define $g=G / Y, k=$ $K / Y$ and use equation (6) to substitute out $w / Y$. Equation (8) becomes:

$$
\gamma[f u+p-(t-q)(1-u)]=(1-u)(1-q)[\tau(1-\gamma)-g)] .
$$

To derive policy effects, we take the total differential of the system, and then simplify the coefficients of the resulting system (that relates the changes in all variables) in two ways. First, we evaluate the coefficients subject to the restrictions implied by the initial full equilibrium. Second, we set the initial values of BI $(p)$ and the employment subsidy $(q)$ equal to zero, and the initial value of $Y$ to unity. We focus on four effects that follow from each policy initiative - the effects on: the unemployment rate $(u)$, the level of productivity $(b)$, the expected income of each individual (who undergoes periods of employment and unemployment, $x$ ), and (in the closed economy only) the income of capitalists $(v)$. The percentage change in expected labour income is given by:

$$
(d x / x)=(d w / w)-((1-u) / \psi) d t-((1-t-f) / \psi) d u+(u / \psi) d f+(1 / \psi) d p
$$

where $\psi=(1-t)(1-u)+u f+p$,

and the percentage change of the income of capitalists (in a closed economy) is given by: 


$$
(d v / v)=(d Y / Y)-(1 /(1-\tau)) d \tau .
$$

Recall that the incomes of the owners of capital are unaffected in the small open economy (given equation (7)).

The formal results are summarized in the appendix. The discussion in the following sections of the text is limited to verbal and graphic analyses.

\section{A Closed Economy}

The most convenient way of appreciating the results in the closed-economy case is by considering Figure 1. This diagram shows the perfectly inelastic supply curve for capital, and the downward sloping marginal product of (demand for) capital curve. The position of the demand curve is affected by the quantity of effective labour, $b L$. For example, an increase in $b L$ increases the marginal product schedule for capital (as shown by the dashed demand curve in Figure 1). Initially, before any such shift, the economy's outcome is given by the intersection of the solid demand and supply curves. Total output $(Y)$ is given by the sum of three areas (numbered 1 through 3 ). Capital owners receive a total income equal to the area of regions 1 and 2, while labour receives a pre-tax-andtransfer level of income equal to region 3.

Now consider the introduction in BI. Since this policy is independent of each individual's employment status, there are no incentive effects. As a result, labour productivity, the unemployment rate, and the wage rate are all unaffected. There is a zero-sum outcome since capital owners are captive. They pay more taxes, and exactly this total is transferred to workers and the unemployed. All that happens in Figure 1 is that an amount of income equal to region 2 is transferred to the workers/unemployed. 
This policy cannot be recommended on the basis of the hypothetical compensation principle, since - if the winners compensated the losers - there would be precisely nothing left over.

A more discouraging result emerges with employment subsidies. This policy does involve incentive effects, so - at first glance - it would seem to be recommended. Firms respond by increasing employment and paying higher wages, and - together - these developments raise the expected income of each individual (variable $x$ ). But there are competing effects on the level of labour productivity. Worker effort is increased by the higher wage rate, but it is decreased by the increased probability that the unemployed can find a job. As proved in the appendix, the latter effect must dominate, so productivity falls. There are competing effects on the overall level of GDP as well, and the value of the formal model is that it allows us to evaluate which effect is stronger. Total output is pushed up by the fact more people are working, but total output is pulled down by the reduction in productivity. Again, as proved in the appendix, the lower productivity effect must dominate. In terms of Figure 1, this means that the marginal product of capital curve shifts down, so that total output (represented by the area under that marginal product schedule) falls. In other words, this initiative generates a negative-sum outcome. The winners (labour) cannot compensate the losers (capital) even if they transfer their entire winnings. By the hypothetical compensation criterion, then, this policy is not recommended.

Finally, consider a cut in the wage-income tax rate financed by a higher tax on capital. Since this policy raises the relative return individuals receive from employment, its direct effect is to push up productivity. This makes it sensible for firms to cut the wage 
premium they had been offering to stimulate productivity, and with lower wages, the unemployment rate falls. It is proved in the appendix that productivity must increase despite the fact that lower pre-tax wages and lower unemployment both push productivity in the opposite direction. The dominant influence is the fact that the lower tax rate makes the after-tax wage higher. In terms of Figure 1, the marginal product curve for capital shifts up since both $b$ and $L$ are higher. Total output is now the sum of areas $1,2,3$ and 4 . With this increase in overall product, the winners can compensate the losers and still have something left over. So, according to the hypothetical compensation principle, this policy is recommended. However, this criterion is unappealing since there is no way for the government to perform this transfer back to capitalists without simply reversing the original initiative.

We conclude that none of the policies represent a Paretian improvement. Thus, according to this model, we should expect resistance to all these policies on the part of the owners of capital. One might expect that the support for these initiatives could be even more limited in the open-economy case, since - in this case - capitalists can protect themselves by migrating away from the higher tax, leaving workers to operate with a lower quantity of capital. We see in the next section, however, that the analysis does not support this conjecture concerning decreased support.

\section{The Open Economy}

The open-economy results are illustrated in Figure 2. In this case, the supply curve for capital is perfectly elastic. There is no change on the demand side of the model, so the downward sloping marginal product relationship appears as in Figure 1, and (as 
before) its position is affected by $b L$. Before any of the policy initiatives, the economy's outcome is given by the intersection of the solid demand and supply curves, and total output $(Y)$ is given by the sum of seven areas (numbered 1 through 7). Capital owners get regions 1, 2 and 3, while labour gets regions 4 through 7.

Before focusing on the model's results, let us use Figure 2 to review the standard analysis of why taxing elastically supplied capital is not recommended. That standard setting involves a competitive labour market (so parameter $b$ is unity), and a fixed labour supply (so $L$ is unity). As a result, there is no mechanism that permits a shift in the position of the capital demand function. When the government raises the tax on capital, the higher (dashed) supply curve becomes relevant. Domestically produced output falls by the sum of regions 1,2,4 and 5. Capital owners do not lose regions 1 and 2, since they now earn this income in the rest of the world. Labour loses regions 4, 5 and 6 , but if the revenue is used to make a transfer to labour, their net loss is just the sum of regions 4 and 5. But this is a loss, so capital is a bad thing to tax.

But if there is a pre-existing distortion, capital can be a good thing to tax. Before illustrating this proposition in Figure 2, we review the original article on the second best (see, Lipsey and Lancaster (1956)). One example discussed in that seminal paper concerned sales taxes in a two-good world. With perfect competition, a tax on just good 2 is not recommended, since this levy makes that price exceed marginal cost, and there is no similar wedge in the other market. But if there is market failure in the first place (say in the form of a monopolist producing good 1), the tax on good 2 can make sense. Now a sales tax on the competitive sector can raise that good's price-to-marginal-cost ratio to what prevails in the monopoly sector, and a selective excise tax is optimal after all. The 
tax in the second sector fixes the initial problem - that the output of good 1 is too small. Figure 2 illustrates a similar situation involving two factors, instead of two goods.

With asymmetric information, the employment of factor 1 (labour) is too small in the second best starting point. A tax on capital induces firms to shift more toward employing labour and that helps lessen the initial distortion. But can this desirable effect of the tax outweigh the traditional excess-burden cost (the loss of income represented by regions 4 and 5 in Figure 2). It appears that this possible. For instance, if the government uses the tax revenue in a way that induces higher labour productivity and/or lower unemployment, the higher $b$ and $L$ values would shift up the marginal product of capital curve in Figure 2. The new outcome is given by the intersection of the dashed demand and supply curves. Total income available to labour is affected in two ways. It is reduced by region 4 (as usual) and it is increased by region 8 . The two questions of interest are: Can we identify a use of the tax revenue that leads to the marginal product curve shifting up, not down? and Can we identify a circumstance in which region 8 can be bigger than region 4 ?

With this intuitive background in place, let us now consider each policy in turn. We begin with BI. As is evident from Figure 2, the financing of BI raises the cost of capital to firms, and it induces them to set a lower wage rate. In this efficiency-wage setting, lower wages lead to lower productivity, so this policy lowers $b$, and the demand for capital curve shifts down, not up. As a result, the total income available for labour shrinks, and this is why average labour income $(x)$ falls. So, with capitalists unaffected and labour losing, BI is not supported by this analysis. 
The analysis is a little more complicated with employment subsidies, since there are two reasons for the marginal product of capital schedule to shift - both $b$ and $L$ adjust. The reduction in unemployment has both favourable and unfavourable effects. The direct (favourable) outcome is that it increases the marginal product of capital, but the indirect (unfavourable) outcome is that (other things equal) increased job prospects and lower wages (as explained above) lead to lower labour productivity (a lower value for $b$ ). It is proved in the appendix that this downward pressure on $b$ must be the dominant consideration, so that both wages $(w)$ and the average labour income $(x)$ must fall. As with BI, then, the demand for capital curve (in Figure 2) shifts down, and the total income available for labour falls. Employment subsidies are not supported by the analysis.

Finally, we consider the balanced budget tax substitution - increasing the tax on capital to finance a tax cut for labour. As with the employment subsidy, unemployment falls, but in this case there are competing effects on labour productivity. As before, increased job prospects lead to decreased work effort, but in this case, the lower tax on employment earnings stimulates increased work effort. It is proved in the appendix that this favourable effect must dominate, so that the work effort index, parameter $b$, rises. With both $b$ and $L$ rising, we finally have an initiative that shifts the marginal product of capital schedule up, as shown in Figure 2.

As noted above, for it to be possible for this tax substitution to represent a Paretian improvement, we must establish that region 8 in Figure 2 can be larger than region 4. As explained in the appendix, an appeal to illustrative parameter values is required to make this case. Up to this point, there have been some ambiguities in some of 
the formal multipliers that are reported in the appendix, but in all cases these uncertainties are resolved by appealing to three simple conditions. A sufficient - though not necessary - set of conditions for all results reported thus far is that the initial unemployment rate be smaller than the replacement rate parameter in the unemployment insurance system, and that this, in turn, be smaller than one minus the initial tax rates:

$$
u<f<(1-t)=(1-\tau)
$$

Since these restrictions are not remotely controversial, we are confident of all results that have been reported. However, to establish the effect on average labour income in this open-economy tax-substitution case, we need to consult illustrative parameter values in a more detailed fashion.

We have considered many sets of representative parameter values, and the results are unaffected by this sensitivity testing. Our baseline parameter assumptions are as follows: $u=.12$ and $f=t=\tau=\gamma=0.33$. These values are based on the assumption that broadly defined capital (which we think of as including skilled labour) receives an income share of 2/3 (as in Mankiw, Romer and Weil (1992)). Since the model involves the assumption that skilled individuals are fully employed, the $u=.12$ assumption implies that the nation's overall unemployment rate is 6 percent if (initially) there are equal numbers of skilled and unskilled individuals. Readers can readily verify that this is one set of parameter values that involves both average labour income, $x$, and work effort, $b$, rising with this balanced budget tax substitution (despite the fact that wages, $w$, fall). Since capitalists are unaffected by this initiative, and since labour is helped - both in terms of lower unemployment and in terms of higher average income - we conclude that 
the analysis supports this policy. It permits income redistribution in a globalized setting, and it requires no new government administration.

To allow readers to have some feel for the possible magnitudes involved with all policies, we note the following implications of the baseline parameter values. If the tax on capital rises by $10 \%$ (by 0.033 ), $x$ falls by $1.3 \%$ with $\mathrm{BI}$; $x$ falls by $1.2 \%$ with employment subsidies; and $x$ rises by $0.9 \%$ with the tax cut for labour. The unemployment rate is unaffected by $\mathrm{BI}$; it falls from $12.0 \%$ to $10.8 \%$ with the employment subsidy; and it falls to $10.7 \%$ with the tax cut for labour.

Finally, it is useful to summarize the differences between the closed and openeconomy analyses. There is some support for those concerned about the proposition that globalization may make low-income support more difficult. As we move to the global case, both BI and employment subsidies shift from being policies that help labour to ones that hurt labour. Also, in the case of BI, the effect of the policy on overall output shifts from one that involves no change to one that reduces the size of the overall economic "pie". But the outcome is different for the wage-income tax cut. Labour wins in both settings, and the overall economic "pie" grows in both cases. But, since there is no political economy problem (no compensation required) in the open-economy case, this policy receives stronger support in the global setting. We conclude that the analysis provides at least a partial response to anti-globalization protesters, since it shows that the scope for at least one low income support policy can be increased by globalization.

As noted in the paper's introduction, we have been heavily influenced by the challenge posed by globalization - does a small open economy have sufficient degrees of freedom to perform meaningful income redistribution? We are drawn to this focus 
because, over time, the assumption of perfect mobility for both capital and skilled labour may become ever more relevant. Since no studies of BI and employment subsidies have focused on the small open-economy constraint, we felt that it was important to start filling at least part of this gap. We conclude that globalization does pose a threat to the efficacy of these policies, but that there is a substitute initiative that appears to be less limited by these constraints.

We close this section by reiterating the intuition that lies behind the support we have found for the tax substitution policy. With an asymmetric information problem and market failure in the labour market (and only one other factor - capital), the optimal tax on capital is no longer zero. Even though capital is supplied elastically, and (therefore) this tax distorts, it permits a lower tax to be paid by labour. This decreases the difference between the net wages of the employed and the income received by those out of work, and this reduces unemployment and increases overall consumption possibilities. This conclusion - that it may make sense to tax internationally mobile capital - is similar to the one derived by Koskela and Schob (2000) in the context of optimal factor income taxation. They note that, in the presence of involuntary unemployment, labour supply is locally infinitely elastic. Thus, the inverse elasticity rule suggests that labour should not be taxed at a higher rate than capital (whose supply is also infinitely elastic at the world rate of interest). Moreover, the presence of unemployment due to the wage rate being higher than the competitive one implies that the private marginal cost of labour is higher than its social marginal cost. Thus, welfare can be increased by taxing the labour input less heavily relative to the capital input (whose social marginal cost equals the world interest rate). ${ }^{4}$ 
It must be admitted that our model does not address the concern that fiscal competition among countries in a world of mobile capital might eliminate the tax on capital as an option (see, for example, Edwards and Keen (1996) and Sinn (1994)). A similar point - applied to mobile skilled labour - is made by Wildasin (1991). But Kessler, Lulfesmann and Myers (2000) have considered mobile capital and labour together. In this setting, fiscal competition is lessened. When redistribution is pursued in one country, the immigration of labour raises the tax base and decreases the incentive to attract capital. Kessler, Lulfesmann and Myers identify circumstances in which increased redistribution in one country makes the majority of the population in both countries (in their two-county model) strictly better off. We conclude that fiscal competition may not undermine the applicability of analyses such as ours after all.

\section{Specification Issues}

In this section, we address two questions - an alternative rationale for unemployment, and issues surrounding the specification for labour supply.

Since there is controversy concerning how best to model unemployment, we consider an alternative to efficiency-wage theory. In particular, in Europe, the role of unions in pushing the wage above market clearing levels is often stressed. Pissarides (1998, p. 162) outlines a compact specification of the interaction between unions and firms. It involves firms choosing employment after the wage is set as a result of a Nash bargaining process. If individuals are risk neutral, and the production process is CobbDouglas, Pissarides shows that the closed-form solution for the unemployment rate is precisely our equation (4) above. In this case, parameter $\alpha$ is defined differently: 
$\alpha=(\varepsilon(1-\gamma)) /(\gamma(1-\varepsilon))$, where, as above, $\gamma$ is labour's exponent in the production function, and $\varepsilon$ is labour's bargaining power parameter in the Nash-product involved in the theory of wage setting. (This parameter determines the share of the surplus resulting from the employment relationship that goes to workers.) The only other changes in the model are that, with unions instead of efficiency wages, parameter $b$ is unity and the exponent for capital in the Cobb-Douglas production function is specified as $\beta$, where $\gamma+\beta<1$, since there must be a surplus to be bargained over.

With the structure of the model almost identical, it is not surprising that many of the results (and the intuition provided by Figures 1 and 2) are the same as what have been explained above. The major difference is that there is an implicit third factor - which we can think of as the entrepreneurs - receiving income equal to $(1-\gamma-\beta) Y$. For the surplus that is bargained over to remain in full equilibrium, we have to assume that the entrepreneurs are not mobile internationally. Thus, we are forced to treat the entrepreneurs in a group along with the (unskilled) workers. This is unappealing since there is not the same public concern about entrepreneurs. Thus, while our results are very similar with unions replacing the efficiency-wage specification (and our analysis therefore passes this sensitivity test), we prefer the efficiency-wage model on motivation grounds.

We now discuss our specification of labour supply. In effect, we assume that labour force participation is independent of the policy changes that are examined. This may seem especially controversial in the case of basic income, since some proponents stress possible differences between BI and other forms of income support on this front. 
As a result, we provide a brief review of the empirical literature concerning the impact of income taxation on work incentives.

The empirical literature on labour supply has identified two margins in which labour supply can respond. First, there is the response along the intensive margin. That is, individuals can vary their hours or effort intensity on the job. If leisure is a normal good, the income and substitution effects of tax changes work in opposite directions. The empirical literature has been at pains to establish the size of the net effect. Killingsworth (1983), Burtless (1986) and Blundell (1992) conclude that the evidence suggests a labour supply elasticity far closer to 0 than to 1 .

Second, individuals may respond along the extensive margin; that is, they decide whether or not to enter the labour force. With respect to the extensive margin, the Negative Income Tax (NIT) experiments and Earned Income Tax Credit (EITC) policies in the United States have provided most of the evidence. It is well established that, relative to a NIT program, incentives to work are enhanced with an EITC because the implicit tax rate inherent in the latter program is smaller. Nevertheless, some authors (for example, Browning (1995) and Eissa and Hoynes (1998)) have still pointed to some problems regarding the incentive structure of the EITC. A major concern in this respect is that the EITC is effectively subsidizing married mothers to stay at home (while it has only a small positive effect on married men's labour supply). Eissa and Hoynes (1998) suggest that a possible reform of the EITC (that it be based on individual earnings as opposed to family earnings) would offset the incentives for secondary earners to leave the labour force. Since the BI proposal provides support to working age individuals (rather than families), it should be less prone to causing reductions in participation rates. This 
consideration, when taken together with the small effects identified by Eissa and Hoynes, lead us to regard the assumption of no effect of BI on aggregate labour force participation as a reasonable approximation of reality.

\section{Conclusions}

Our analysis of basic income and employment subsidies has drawn attention to some of the complications that follow from the financing of these initiatives. Even in a closed-economy setting, the analysis identifies political economy questions concerning how such policies can achieve support when segments of the population suffer income losses. The analysis indicates that these concerns are increased in the open-economy setting, where those who are taxed have an increased ability to avoid any loss in income. Nevertheless, we have stressed that in a second-best initial situation, Paretian improvements are possible. Further, a balanced budget tax substitution was identified as one initiative that could thereby avoid any political economy support problem - even in a global setting. We think that the identification of this possibility should allay some of the fears of those who think that globalization may weaken our ability to effect low-income support policy in a small economy. The analysis suggests that more research on tax substitutions of this sort may bring at least as big a return as will further analysis of basic income and employment subsidies.

In related work, we have begun some of this additional investigation. We are considering a specification of technology that allows for an explicit difference between skilled labour and physical capital (with the former being essential in the production process). Also, we allow the skilled individuals to save (so that their consumption and 
income are not identical, and so that the analysis allows for the effects of each policy initiative on long-run wealth accumulation). Preliminary results suggest that some of these changes in model specification can increase the support for basic income and/or employment subsidies. We hope that the present paper stimulates others to work on extensions such as this one.

Of course, even with extensions, it may not be possible to incorporate within the analysis all aspects of the debate concerning basic income and employment subsidies. For example, proponents of BI stress issues such as its beneficial effects on the level of real freedom for disadvantaged groups, while some opponents stress self-sufficiency and the value people derive from making a contribution through employment. These wider philosophical issues are well summarized in the debate between Phelps (2000) and Van Parijs (2000) in the Boston Review. Some of these wider issues can be included in an extended version of our analysis. One relates to the encouragement of work sharing, and a second to reductions in administrative costs. (BI would do away with complicated means-tested benefits.) Another issue stressed by proponents of the BI is that - when it replaces unemployment insurance - it offers incentives for skill acquisition. It remains to be explored how BI may affect behaviour if it also replaces a public pension system. Nevertheless, our work in progress involving a formal skilled-unskilled distinction and long-run wealth accumulation are designed to allow theses issues to be explored. In the meantime, it is hoped that the present paper has clarified some of the basic macroeconomic trade-offs involved with the provision of basic income and employment subsidies. 


\section{Appendix}

For the closed economy, the policy results are as follows.

With BI, $d u / d \tau=(d w / w) / d \tau=(d b / b) / d \tau=(d Y / Y / d \tau)=0$.

Also, $(d v / v) / d \tau=-1 /(1-\tau))<0$, and $(d x / x) d \tau=[(1-u)(1-\gamma)] /(\gamma \psi)>0$.

With the employment subsidy,

$d u / d \tau=-(u(1-\gamma)(1-u)) / \gamma \lambda<0$

$(d w / w) / d \tau=[(1-u)(1-\gamma)(1-\alpha \gamma-(u(1-\gamma)) /(1-u))] /[\gamma \lambda(1-\alpha \gamma)]>0$

$\lambda=\psi-(u f /(1-u)>0$

$(d b / b) / d \tau=-[\alpha u(1-\gamma)(1+\gamma)] /[\gamma(1-\alpha \gamma) \lambda]<0$

$(d Y / Y) / d \tau=-[\alpha \mu(1-u)(1-\gamma)] /[\gamma \lambda(1-\alpha \gamma)]<0$.

With the wage-income tax cut,

$d u / d \tau=-((1-\gamma)(1-u)(u-\alpha)) / \gamma \Omega \phi<0$

$$
\begin{aligned}
& \Omega=1-t-f>0 \\
& \phi=1-u-[(f(u-\alpha)) /(\Omega(1-u))]>0
\end{aligned}
$$

$(d x / x) / d \tau=[(1-u)(1-\gamma) \theta] /[\gamma \phi(1-\alpha \gamma)]>0$

$$
\theta=\left[(u-\alpha)(1-\alpha \gamma)[(\Omega / \psi)-(1 /(\Omega(1-u))]]+[(1-u)(1-\alpha \gamma) / \psi]+\left[\alpha \gamma^{2} / u \Omega\right]>0\right.
$$

$(d Y / Y) / d \tau=(1-u)(1-\gamma)\left[\left(\alpha^{2} / u\right)+((1-\alpha)(u-\alpha) /(1-u))\right] /[\Omega \phi(1-\alpha \gamma)]>0$

$(d v / v) / d \tau<0$

Not all the signs reported are certain a priori. Nevertheless, as noted in the text, sufficient - though not necessary - conditions for all but the very last result are:

$$
u<f<(1-t)=(1-\tau) .
$$


Since these restrictions are not at all controversial, we can be confident of the signs that are reported.

For the small open economy, the policy results are as follows $\left(\mathrm{a}^{\wedge}\right.$ over a variable denotes proportional change).

With BI,

$d u / d \tau=0$

$\hat{w} / d \tau=-(1-\gamma) /(\gamma(1-\tau)(1-\alpha))<0$

$\hat{b} / d \tau=-(\alpha(1-\gamma)) /((1-\tau)(1-\alpha) \gamma)<0$

$\hat{x} / d \tau=((1-\gamma) \delta) / \gamma<0$

$$
\delta=(1 /[(1-t)+(u f /(1-u))])-(1 /[(1-\tau)(1-\alpha)])<0
$$

With the employment subsidy,

$d u / d \tau=-(u(1-\gamma)(1-u)) / \gamma \lambda<0$

$\hat{w} / d \tau=(1-\gamma)[(1-u)(1-\alpha)-(\lambda /(1-\tau))] /(\gamma(1-\alpha) \lambda)<0$

The $x$ response is calculated from these component multipliers (as in earlier cases). The result is unsigned. Nevertheless, we have experimented with many parameter values, and the results are unaffected. Readers may wish to use our baseline parameter assumptions: (noted in the text) to verify that, for representative parameter assumptions, $x$ falls with the introduction of employment subsidies.

With the wage-income tax cut,

$d u / d \tau=-((1-\gamma)(1-u)(u-\alpha)) / \gamma \Omega \phi<0$

$\hat{w} / d \tau=-(1-\gamma)\left[(\phi /(1-\tau))-\left(\alpha^{2}(1-u) /(u \Omega)\right)\right] /[\gamma \phi(1-\alpha)]<0$

$\hat{b} / d \tau=-[(\alpha(1-\gamma)) /(\gamma(1-\alpha) \phi)][(\phi /(1-\tau))-(\alpha(1-u) /(\Omega u))]>0$ 


\section{References}

Akerlof, G. and J. Yellen, (eds.), 1986, Efficiency Wage Models of the Labor Market, (Cambridge: Cambridge University Press).

Atkinson, A., 1995, Public Economics in Action: The Basic Income/Flat Tax Proposal (Oxford: Oxford University Press).

Atkinson, A., 1999, The Economic Consequences of Rolling Back the Welfare State, (Cambridge, Mass: MIT Press).

Atkinson, A., and H. Sutherland, 1990, "Scaling the 'Poverty Mountain': Methods to Extend Incentives to All Workers," in A. Bowen and K. Mayhew (eds.), Improving Incentives for the Low Paid, (London: Macmillan).

Bergmann, B. R., 2001, “A Swedish-Style Welfare State or Basic Income: Which Should Have Priority?” USBIG Discussion Paper No. 10.

Blundell, R. W., 1992, “ Labour Supply and Taxation: A Survey,” Fiscal Studies 13, 1540 .

Blundell, R. W., and T. MaCurdy, 1999, "Labour Supply: A Review of Alternative Approaches," in O. Ashenfelter and D. Card (eds.), Handbook of Labour Economics, Volume 3A, (Amsterdam: North-Holland).

Bowles, S., 1992, "Is Income Security Possible in a Capitalist Economy? An AgencyTheoretic Analysis of an Unconditional Income Grant," European Journal of Political Economy 8, 557-578.

Brewer, M. and P. Gregg, 2001, "Eradicating Child Poverty in Britain: Welfare Reform and Children since 1997”, IFS Discussion Paper 01/18.

Browning, E., 1995, “ Effects of the Earned Income Tax Credit on Income and Welfare,” National Tax Journal 48, 23-43.

Burtless, G., 1986, "The Work Response to a Guaranteed Income: A Survey of Experimental Evidence," in A. H. Munnell (ed.), Lessons from the Income Maintenance Experiments, (Boston: Federal Reserve Bank of Boston, Conference Series No. 30).

Edwards, J. and M. Keen, 1996, "Tax Competition and Leviathan," European Economic Review 40, 113-134.

Eissa, N., and H.W. Hoynes, 1998, "The Earned Income Tax Credit and the Labour Supply of Married Couples," NBER Working Paper No. 6856. 
Esping-Andersen, G., 1990, The Three Worlds of Welfare Capitalism, (Cambridge, UK: Polity Press).

Freeman, R., 1995, “Are your Wages Set in Beijing?” Journal of Economic Perspectives 9, 15-32.

Gordon, D. N., 1996, Fat and Mean: The Corporate Squeeze of Working Americans and the Myth of Managerial "Downsizing” (New York: The Free Press).

Groot, L., and H. Peters, 1997, "A Model of Conditional and Unconditional Social Security in an Efficiency Wage Economy," Journal of Post-Keynesian Economics 19, 573-597.

Heady, C., T. Mitrakos, and P. Tsakloglou, 2001, "The Distributional Impact of Social Transfers in the European Union: Evidence from the ECHP," Fiscal Studies 68, 547-565.

Kessler, A., C. Lulfesmann and G. Myers, 2000, "Redistribution, Fiscal Competition and the Politics of Economic Integration," Simon Fraser University, Department of Economics, Discussion Paper 00-11.

Killingsworth, M. R., 1983, Labour Supply, (Cambridge: Cambridge University Press).

Koskela, E., and R. Schob, 2000, "Optimal Factor Income Taxation in the Presence of Unemployment," CESifo Working Paper No. 279.

Lipsey, R. G., and K. Lancaster, 1956, “The General Theory of the Second Best,” Review of Economic Studies 24, 11-32.

Machin, S. and J. Van Reenen, 1998, "Technology and Changes in Skill Structure: Evidence from Seven OECD Countries," Quarterly Journal of Economics 113, 12151244.

Mankiw, N.G., D. Romer and D. Weil, 1992, "A Contribution to the Empirics of Economic Growth”, Quarterly Journal of Economics 107, 407-437,

Manning, A., 1995, "How Do We Know that Real Wages are Too High?" Quarterly Journal of Economics 110, 1111-1126.

Meade, J., 1948, Planning and the Price Mechanism (London: Allen and Unwin).

Meade, J., 1972, "Poverty in the Welfare State," Oxford Economic Papers 24, 289-326.

Phelps, E., 1997, Rewarding Work (Cambridge, Mass.: Harvard University Press).

Phelps, E., 2000, “Subsidize Wages,” Boston Review 25, 5. 
Pissarides, C., 1998, “The Impact of Employment Tax Cuts on Unemployment and Wages: The Role of Unemployment Benefits and Tax Structure," European Economic Review 42, 155-183.

Rebitzer, J. and L. Taylor, 1995, "The Consequences of Minimum Wage Laws: Some New Theoretical Ideas," Journal of Public Economics 56, 245-256.

Rodrik, D., 1997, Has Globalization Gone too Far? (Washington, DC: Institute of International Economics).

Shapiro, C., and J. Stiglitz, 1984, "Equilibrium Unemployment as a Worker Discipline Device," American Economic Review 74, 433-444.

Sinn, H.-W., 1994, "How Much Europe? Subsidiarity, Centralization, and Fiscal Competition," Scottish Journal of Political Economy 41, 85-107.

Sinn, H.-W., 1995, “A Theory of the Welfare State," Scandinavian Journal of Economics 97, 495-526.

Solow, R., 1998, Work and Welfare (Princeton, N.J.: Princeton University Press).

Summers, L., 1988, "Relative Wages, Efficiency Wages and Keynesian Unemployment," American Economic Review, Papers and Proceedings 78, 383-388.

Tobin, J., J. Pechman and P. Mieszkowski, 1967, “Is a Negative Income Tax Practical?" Yale Law Journal 77, 1-27.

Van der Linden, B., 1999, "Is Basic Income a Cure for Unemployment in Unionized Economies? A General Equilibrium Analysis," Document de Travail No. 49, Chaire Hoover d' Ethique Economique et Sociale, Universite Catholique de Louvain.

Van der Linden, B., 2000, "Fighting Unemployment Without Worsening Poverty: Basic Income versus Reductions of Social Security Contributions," in W. Salverda, B. Nolan and C. Lucifora (eds.), Policy Measures for Low-Wage Employment in Europe (Cheltenham, UK: Edward Elgar).

Van Parijs, P., 1992, Arguing for Basic Income: Ethical Foundations for a Radical Reform, (London : Verso).

Van Parijs, P., 1995, Real Freedom for All: What (If Anything) Can Justify Capitalism? (New York: Oxford University Press).

Van Parijs, P., 2000, “A Basic Income for All,” Boston Review 25, 5.

Wildasin, D., 1991, "Income Redistribution in a Common Labor Market," American Economic Review 81, 757-774. 
Wood, A., 1994, North-South Trade, Employment and Inequality (Oxford, UK: Clarendon Press).
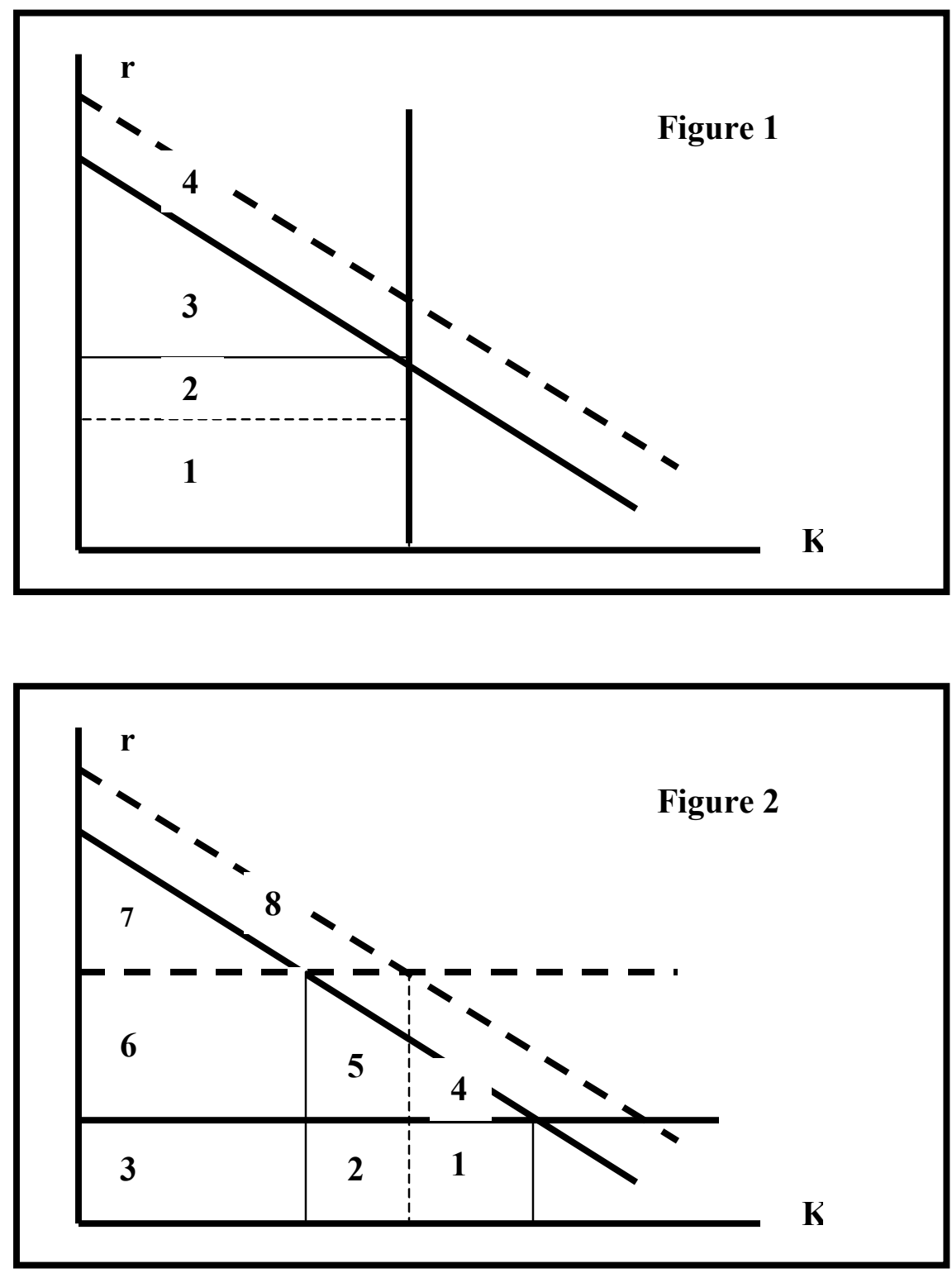


\section{Endnotes}

${ }^{1}$ Some economists have pointed to alternative explanations, such as a shift in relative demand in favour of skilled labour. Others, for example, Gordon (1996), has argued that the weakening of labour market institutions and the erosion of the real value of the minimum wage are responsible for the increased inequality in the United States.

${ }^{2}$ The BI proposal, although it can be traced as far back as Augustin Cournot and John Stuart Mill, must be seen in tandem with the current policy trend in many OECD countries to "make work pay". By conferring tax credits and benefits to employees, policy makers in many countries attempt to increase employment and net incomes of low-wage earners without imposing too large a burden on the state's budget (e.g. the Earned Income Tax Credit (EITC) in the US, the Child Tax Benefit in Canada and the Working Families' Tax Credit in the UK). Nevertheless, the measures implemented do not aim at guaranteeing a subsistence level. All these programs are conditional on employment, and the level of the implied subsidy is inversely related to the income (or hours of work) of the recipients. To the proponents of BI, this is the Achilles' heel of these programs, since the implied marginal tax rate for households in the phase-out range of these programs can be as high as 80 percent (see, Brewer and Gregg (2001)).

${ }^{3}$ Following Esping-Andersen (1990) we can identify four "models of welfare capitalism" in the EU: the Scandinavian model of universal social protection as a right of citizenship; the 'Bismarckian' employment-based model of Germany, Austria, France and the Benelux countries; the Anglo-Saxon model of the United Kingdom and Ireland; and the fragmented and highly idiosyncratic arrangements of the remaining southern EU members. Also, Heady, Mitrakos and Tsakloglou (2001) document the very large variance of social transfers in the EU. Social transfers as a percentage of GDP vary between $16.9 \%$ (Portugal) to 37.6\% (Sweden). Wide differences also exist in the allocation of such transfers by type of benefit ( for example, family related benefits account for $0.7 \%$ of total social transfers in Spain and for $15.2 \%$ in Ireland), by their impact on inequality ( the proportional decline in the Gini index of inequality due to social tranfers in cash varies between $46 \%$ for Denmark and $22.7 \%$ for Portugal), and in poverty (the existence of unemployment benefits reduces poverty by $66.4 \%$ in Denmark and by $1.7 \%$ in Greece).

${ }^{4}$ Others (such as Manning (1995) and Rebitzer and Taylor (1995)) have shown that - in such a second-best setting - other non-standard results can emerge. For example, in their efficiency-wage models, minimum wage laws can raise employment. We have verified that this is not possible in Summers' version of efficiency wage theory that we rely on in this paper. 


\title{
CESifo Working Paper Series
}

\author{
(for full list see www.cesifo.de)
}

852 Gregory D. Hess, The Economic Welfare Cost of Conflict: An Empirical Assessment, February 2003

853 Douglas J. Cumming and Jeffrey G. MacIntosh, Comparative Venture Capital Governance. Private versus Labour Sponsored Venture Capital Funds, February 2003

854 Eckhard Janeba and John Douglas Wilson, Decentralization and International Tax Competition, February 2003

855 Tapio Palokangas, Capital Accumulation and Employment Cycles in a Model of Creative Destruction, February 2003

856 Brendan Walsh, When Unemployment Disappears: Ireland in the 1990s, February 2003

857 Luis H. R. Alvarez and Erkki Koskela, A General Approach to the Stochastic Rotation Problem with Amenity Valuation, February 2003

858 Christian Schultz, Strategic Campaigns and Redistributive Politics, February 2003

859 Ernst Fehr and Joseph Henrich, Is Strong Reciprocity a Maladaptation? On the Evolutionary Foundations of Human Altruism, February 2003

860 Haizhou Huang, Dalia Marin, and Chenggang Xu, Financial Crisis, Economic Recovery and Banking Development in Former Soviet Union Economies, February 2003

861 Pedro Cardoso and Bernard M.S. van Praag, How Sustainable Are Old-age Pensions in a Shrinking Population with Endogenous Labour Supply?, February 2003

862 Volker Meier, Efficient Transfer of Aging Provisions in Private Health Insurance, February 2003

863 Edward Castronova, Theory of the Avatar, February 2003

864 Robert S. Chirinko, Hans van Ees, Harry Garretsen, and Elmer Sterken, Investor Protections and Concentrated Ownership: Assessing Corporate Control Mechanisms in the Netherlands, February 2003

865 Bernard M.S. van Praag and Pedro Cardoso, The Mix Between Pay-as-you-go and Funded Pensions and what Demography has to do with it, February 2003

866 Ernst Fehr, Urs Fischbacher, Bernhard von Rosenbladt, Jürgen Schupp, and Gert G. Wagner, A Nation-Wide Laboratory. Examining Trust and Trustworthiness by Integrating Behavioral Experiments into Representative Survey, February 2003 
867 Frank Heinemann, The Inflationary Impact of Wage Indexation, February 2003

868 Eytan Sheshinski, Bounded Rationality and Socially Optimal Limits on Choice in a Self-Selection Model, February 2003

869 M. Hashem Pesaran, Estimation and Inference in Large Heterogenous Panels with Cross Section Dependence, February 2003

870 Luis H. R. Alvarez and Erkki Koskela, On the Tree-Cutting Problem under Interest Rate and Forest Value Uncertainty, February 2003

871 Norbert Berthold and Rainer Fehn, Unemployment in Germany: Reasons and Remedies, February 2003

872 Clemens Fuest, Bernd Huber, and Philipp Tilleßen, Tax Policy and Entrepreneurship in the Presence of Asymmetric Information in Capital Markets, February 2003

873 Eytan Sheshinski, Optimum and Risk-Class Pricing of Annuities, February 2003

874 Willi Leibfritz, Paul O'Brien and Jean-Christophe Dumont, Effects of Immigration on Labour Markets and Government Budgets - An Overview, February 2003

875 M. Hashem Pesaran and Allan Timmermann, How Costly is it to Ignore Breaks when Forecasting the Direction of a Time Series?, February 2003

876 Thorvaldur Gylfason and Gylfi Zoega, Education, Social Equality and Economic Growth: A View of the Landscape, February 2003

877 Robin Boadway and Jean-François Tremblay, Public Economics and Startup Entrepreneurs, February 2003

878 Erkki Koskela and Roope Uusitalo, The Un-Intended Convergence: How the Finnish Unemployment Reached the European Level, February 2003

879 Robert Fenge and Volker Meier, Pensions and Fertility Incentives, February 2003

880 Eytan Sheshinski, Note on Income Taxation and Occupational Choice, February 2003

881 A B Atkinson, Income Inequality in OECD Countries: Data and Explanations, February 2003

882 Thomas Gehrig and Rune Stenbacka, Venture Cycles: Theory and Evidence, February 2003

883 Ralf Becker and Thomas Hellmann, The Genesis of Venture Capital - Lessons from the German Experience, March 2003

884 Eytan Sheshinski, Note on the Optimum Pricing of Annuities, March 2003

885 Paul De Grauwe and Magdalena Polan, Globalisation and Social Spending, March 2003 
886 F. van der Ploeg, Do Social Policies Harm Employment and Growth?, March 2003

887 Mirjam van Praag, Initial Capital Constraints Hinder Entrepreneurial Venture Performance: An empirical analysis, March 2003

888 Bernard Steunenberg, Coordinating Sectoral Policymaking: Searching for Countervailing Mechanisms in the EU Legislative Process, March 2003

889 Eytan Sheshinski, Optimum Delayed Retirement Credit, March 2003

890 Frederick van der Ploeg, Rolling Back the Public Sector - Differential effects on employment, investment and growth, March 2003

891 Paul De Grauwe and Marc-Alexandre Sénégas, Monetary Policy in EMU when the Transmission is Asymmetric and Uncertain, March 2003

892 Steffen Huck and Kai A. Konrad, Strategic Trade Policy and the Home Bias in Firm Ownership Structure, March 2003

893 Harry Flam, Turkey and the EU: Politics and Economics of Accession, March 2003

894 Mathias Hoffmann and Ronald MacDonald, A Re-examination of the Link between Real Exchange Rates and Real Interest Rate Differentials, March 2003

895 Badi H. Baltagi, Espen Bratberg, and Tor Helge Holmås, A Panel Data Study of Physicians' Labor Supply: The Case of Norway, March 2003

896 Dennis C. Mueller, Rights and Citizenship in the European Union, March 2003

897 Jeremy Edwards, Gains from Trade in Tax Revenue and the Efficiency Case for Trade Taxes, March 2003

898 Rainer Fehn and Thomas Fuchs, Capital Market Institutions and Venture Capital: Do They Affect Unemployment and Labour Demand?, March 2003

899 Ronald MacDonald and Cezary Wójcik, Catching Up: The Role of Demand, Supply and Regulated Price Effects on the Real Exchange Rates of Four Accession Countries, March 2003

900 R. Selten, M. Schreckenberg, T. Pitz, T. Chmura, and S. Kube, Experiments and Simulations on Day-to-Day Route Choice-Behaviour, April 2003

901 Stergios Skaperdas, Restraining the Genuine Homo Economicus: Why the Economy Cannot be Divorced from its Governance, April 2003

902 Yin-Wong Cheung, Menzie D. Chinn, and Antonio Garcia Pascual, What Do We Know about Recent Exchange Rate Models? In-Sample Fit and Out-of-Sample Performance Evaluated, April 2003

903 Mika Widgrén, Enlargements and the Principles of Designing EU - Decision-Making Procedures, April 2003 
904 Phornchanok Cumperayot, Dusting off the Perception of Risk and Returns in FOREX Markets, April 2003

905 Kai A Konrad, Inverse Campaigning, April 2003

906 Lars P. Feld and Stefan Voigt, Economic Growth and Judicial Independence: Cross Country Evidence Using a New Set of Indicators, April 2003

907 Giuseppe Bertola and Pietro Garibaldi, The Structure and History of Italian Unemployment, April 2003

908 Robert A.J. Dur and Otto H. Swank, Producing and Manipulating Information, April 2003

909 Christian Gollier, Collective Risk-Taking Decisions with Heterogeneous Beliefs, April 2003

910 Alexander F Wagner, Mathias Dufour, and Friedrich Schneider, Satisfaction not Guaranteed - Institutions and Satisfaction with Democracy in Western Europe, April 2003

911 Ngo Van Long, Raymond Riezman, and Antoine Soubeyran, Trade, Wage Gaps, and Specific Human Capital Accumulation, April 2003

912 Andrea Goldstein, Privatization in Italy 1993-2002: Goals, Institutions, Outcomes, and Outstanding Issues, April 2003

913 Rajshri Jayaraman and Mandar Oak, The Signaling Role of Municipal Currencies in Local Development, April 2003

914 Volker Grossmann, Managerial Job Assignment and Imperfect Competition in Asymmetric Equilibrium, April 2003

915 Christian Gollier and Richard Zeckhauser, Collective Investment Decision Making with Heterogeneous Time Preferences, April 2003

916 Thomas Moutos and William Scarth, Some Macroeconomic Consequences of Basic Income and Employment Subsidies, April 2003 